Derleme

D Vitamini ve Depresyon

D Vitamini Yetersizliği ve Depresyon: Ne Yapabiliriz?

\author{
Nesli Ersoy ${ }^{1}$, Gülgün Ersoy ${ }^{2}$ \\ ${ }^{1}$ Hacettepe Üniversitesi, Sağlık Bilimleri Fakültesi, Beslenme ve Diyetetik Bölümü \\ ${ }^{2}$ İstanbul Aydın Üniversitesi, Sağllk Bilimleri Fakültesi, Beslenme ve Diyetetik Bölümü
}

\begin{abstract}
Özet
D vitamini yetersizliği özellikle Batı toplumlarında yaygın olarak görülmektedir. D vitamininin kemik sağlı̆̆ı açısından etkileri giderek anlaşılmasına karşın, henüz diğer sağlık alanlarında, özellikle mental sağlık alanındaki etkileri yeterince belirlenmemiştir. D vitaminin birçok kronik hastalığın patofizyolojisi ve ilerlemesinde rolü olduğu bilinmesine karşın, son yapılan çalışma verileri, D vitamini yetersizliğinin özellikle güneş ışığını sınırlı alanlar, yaşlılar, gebe ve çocuklar gibi bazı risk gruplarında yaygın olduğunu göstermektedir. Serum D vitamininin düşük olması depresyon, anksiyete ve stres ile ilişkili olabileceği belirtilmektedir. D vitamini ve depresyon arasındaki ilişkiyi güçlendiren en önemli bilginin beynin birçok alanında $\mathrm{D}$ vitamini reseptörleri saptanması ve 25(OH)D'yi 1.25(OH)D'ye metabolize eden 1- $\alpha$ hidroksilaz enziminin önemli immüno reaktivite göstermesinin olduğu öne sürülmüştür. Serum D vitamini düzeyinin düşük olması ve depresyon patofizyolojisi üzerine birçok araştırma bulunmasına karşın, depresyon tedavisinde D vitamini suplemantasyonunun rolü konusunda daha fazla çalışmaya gerek duyulmaktadır. D vitamini yetersizliğinin ülkemiz içinde halen bir halk sağlığı sorunu olduğu unutulmamalıdır ve depresyon ile düşük serum D vitamini düzeyleri arasında ilişki nedeniyle, özellikle depresyon hikâyesi olan kişilerde serum D vitamini düzeylerinin saptanması önerilebilir.
\end{abstract}

Anahtar kelimeler: D vitamini, depresyon, beslenme

Sorumlu Yazar: Nesli Ersoy, Hacettepe Üniversitesi, Sağlık Bilimleri Fakültesi, Beslenme ve Diyetetik Bölümü. Hacettepe Üniversitesi, Sağlık Bilimleri Fakültesi, Beslenme ve Diyetetik Bölümü, Sihhiye, Ankara. Telefon: 0(312)305 10 96, E-posta: nesli.arpaci@ hacettepe.edu.tr 
Review

\title{
Vitamin D and Depression
}

\section{Vitamin D deficiency and Depression: What Can We Do?}

\author{
Nesli ERSOY ${ }^{1}$, Gülgün ERSOY ${ }^{2}$ \\ ${ }^{1}$ Hacettepe University, Faculty of Health Sciences, Department of Nutrition and Dietetics \\ ${ }^{2}$ Istanbul Aydin University, Faculty of Health Sciences, Department of Nutrition and Dietetics
}

\begin{abstract}
Vitamin D deficiency is known to be widely in Western populations. The implications of this in terms of bone health are increasingly understood, yet its impact on other health areas, particularly mental health, is unclear. Although recent data shown that vitamin D has an important impact on pathophysiology and progression of serious chronic illness, vitamin D deficiency may be common, especially in the risk groups who utilize limited sunshine such as elderly, pregnant and children. Low vitamin D levels are associated with depression, poor mood and other mental disorders. Most important data about relationship between vitamin D and depression is determination of vitamin D receptors at most area in brain and immüno reactivity of 1-alpha-hydroxylase that convert to $1.25(\mathrm{OH}) \mathrm{D}$ from $25(\mathrm{OH})$. Although there are a number of trials that have suggested a role on lower serum vitamin D level and pathophysiology of depression, more studies were need about vitamin D supplementation on treatment of depression. Vitamin D deficiency is still major public health problem for our country. Primarycare patients with a history of depression may be an important target for assessment of vitamin D levels.
\end{abstract}

Keywords: Vitamin D, depression, nutrition

Corresponding Author: Nesli Ersoy, Hacettepe University, Faculty of Health Sciences, Department of Nutrition and Dietetics, Sihhiye, Ankara. Phone: 0(312)305 10 96, E-mail: nesli.arpaci@hacettepe.edu.tr 


\section{Giriş}

İnsanlık tarihinin başlangıcından bu yana; edebiyatta, görsel sanatlarda ve dinde, mutluluk ile pozitif duygular; güneş, bahar, sıcak ve açık hava ile ilişkilendirilmiştir. Koyu renkli, kapalı hava, kirli bir gökyüzü ve kentsel çevreler ise mutsuzluk ve korkunun sembolü olmuştur (Humble, 2010). Depresyon yüksek prevelansa sahip, önemli bir halk sağlı̆̆ sorunudur (Penckofer, Kouba ve Byrn, 2010). Depresyon, Dünya Sağlık Örgütü (WHO, 2008) verilerine göre en çok görülen hastalıklar listesinde 4. sırada yer almakta ve bu şekilde artmaya devam ederse, 2020 yılında dünyada en çok görülen 2. hastalık olacağ1 öne sürülmektedir.

Depresyon en az iki hafta süren bir dönem süresince, hemen hemen tüm aktivitelerde depresif bir ruh hali veya ilgi-zevk kaybı ile karakterize bir durumdur. İştah, uyku ve psikomotor fonksiyon değişiklikleri, sinirlilik, değersizlik duyguları, suçluluk, umutsuzluk ve intihar düşüncesi veya girişimi ayrıca tüm bu belirtilere ek olarak enerji azalması görülmektedir. Majör depresif bozukluk, normal yaşam aktivitesi ve sosyal ilişkilerde önemli bozulmalara neden olmakta ve kadınlarda (\%10-25) erkeklere göre (\%5-12) daha s1k görülmektedir. Ortalama başlangıç yaşı, yirmili yaşların ortalarıdır ve tek bir depresif atak yaşayanların \%50-60’ında depresyon tekrarlamakta ve çoğu zaman anksiyete ile birlikte görülmektedir (Bertone-Johnson, 2009).

Son yıllarda birçok kronik hastalığın korunmasında ve tedavisinde D vitamininin önemli bir yeri olduğu bildirilmektedir (CADTH, 2015; McGreevy, Barry ve Davenport, 2015; Wong, 2015). Depresyonu etkileyen beyin bölgelerinde D vitamini reseptörlerinin tanımlanması, D vitamini ve depresyon arasındaki ilişkiyi güçlendirmiştir. İnsan ve hayvan çalışmalarında, D vitamini reseptörleri ve 1- $\alpha$-hidroksilaz enziminin beyinde bulunduğu ve merkezi sinir sistemi fonksiyonlarında D vitamininin rolü olduğu gösterilmiştir (Eyles, Smith, Kinobe, Hewison ve McGrath, 2005; Prüfer, Veenstra, Jirikowski ve Kumar, 1999). Depresyon ve diğer mental bozukluk olan bireylerde serum D vitamini düzeyleri düşük bulunmuştur (Penckofer, Kouba ve Byrn, 2010; Anglin, Samaan, Walter ve Mc Donald, 2013). Bu veriler, güneş ışı̆̆ına yeterince maruz kalınmaması ile mevsimsel depresyon riskinin artması arasındaki ilişkiyi mantıklı bir şekilde açıklamakta ve depresyon tedavisinde D vitamini desteğinin potansiyel yararlı etkileri olabileceğine dikkati çekmektedir (Howland, 2011). 
Bu derlemede; D vitamini düzeyi ve depresyon ile D vitamini suplemantasyonu ve depresyon tedavisi arasındaki ilişkiyi hem destekleyen hem de desteklemeyen çalışmalar özetlenerek, konu ile ilgili çıkarımların yapılması amaçlanmıştır.

\section{Vitamini Metabolizması ve Kaynakları}

D vitamininin temel olarak; bitkisel kaynaklı $\mathrm{D}_{2}$ vitamini (ergokalsiferol), hayvansal kaynaklı (kolekalsiferol) ve güneş ışınlarından sağlanan (ultraviyole B radyasyon, deri üzerindeki 7-dehidrokolesterolü vitamin $\mathrm{D}_{3}$ 'e çevirmektedir) $\mathrm{D}_{3}$ vitamini (kolekalsiferol) olmak üzere iki şekli vardır. Her iki şekli de, karaciğerde $25(\mathrm{OH}) \mathrm{D}_{3}$ 'e çevrilmektedir. Böbreklerde 1- $\alpha$-hidroksilaz enzimi ile $25(\mathrm{OH}) \mathrm{D}_{3},\left(1,25(\mathrm{OH})_{2} \mathrm{D}_{3}\right)$ 'ye çevrilerek, biyolojik olarak aktif hale gelmekte ve vitamin D reseptörlerine bağlanarak, vücutta fizyolojik fonksiyonlarını düzenlemektedir (Howland, 2011).

D vitamini için en iyi kaynak, derideki 7-dehidrokolesterolden ultraviyole-B radyasyonuna maruz kaldıktan sonra oluşan endojen kaynaklı $\mathrm{D}_{3}$ vitaminidir. D vitamininin \%90'dan fazlası güneş 1şığına maruz kalınması ile sentezlenmektedir. Yağlı balıklar, ringa, uskumru ve ton balığı D vitamininden doğal olarak zengindir. Amerika ve bazı Avrupa ülkelerinde; süt, yoğurt, portakal suyu, tahıllar D vitamini ile zenginleştirilmektedir (Baysal, 2012).

\section{Vitamini Yetersizliği Riski Olan Gruplar}

D vitamini yetersizliği veya eksikliği yönünden yüksek risk taşıyanlar; güneş ışığını sınırlı alanlar, yaşlılar, gebeler ve çocuklardır. D vitamini eksikliğinin belirtileri, yaşa, eksikliğin ve/veya yetersizliğin şiddetine bağlı olarak değişmektedir. D vitamini yetersizliğine bağlı olarak çocuklarda gelişen raşitizmin belirtileri değişiklik göstermekle beraber; kemik ağrısı, diş çıkarmada gecikme ve büyüme geriliği bu belirtilere örnek olarak gösterilebilir. Güneşten yayılan ultraviyole ışınlarının zararlı etkileri ile ilgili uyarılar yapılması sonucu 1980'li yıllardan sonra, ebeveynler çocuklarını güneşin zararlı ışınlarına karşı korumaya teşvik edilmişlerdir. Güneş 1şınlarından yararlanma süresindeki azalmaya paralel olarak özellikle çocuklarda ve gençlerde depresyon giderek yaygınlaştığı ve otizm spektrom bozukluklarında artış olduğu gösterilmiştir (Humble, 2010; Berk ve diğerleri, 2007). Yetişkinlerde ise; kas güçsüzlüğü, kemik ağrısı, yürümede zorluk ve sık düşmeler görülebilmektedir (Penckofer, Kouba ve Byrn, 2010).

Sağlıksız beslenen ve iyi yaşam koşulları sürdürmeyen gençlerde de, D vitamini eksikliği görülmekte ve bu gençlerde depresyon görülme sıklığı giderek artmaktadır. Bu yaş 
grubunda depresyon nedenlerini net bir şekilde saptayabilmek için yeni biyolojik belirteçlerin saptanması öngörülmekte, D vitamini düzeyinin değerlendirmeye alınması gerektiği ileri sürülmektedir (Williams, Novick, ve Lehman, 2014; Kwasky ve Groh, 2012). D vitamini düzeyinin psikolojik durum üzerine etkisinin araştırıldığı yirmi yıllık izlem çalışmasında, erkek çocuklarında serum D vitamini düzeyinde $10 \mathrm{nmol} / \mathrm{L}$ artışın depresyon-anksiyete-stres skorlamasında azalmaya neden olduğu, kız çocuklarında ise benzer bir etkinin gözlenmediği gösterilmiştir (Black ve diğerleri, 2014). 139 genç kadın (18-24 yaş) üzerinde depresyon ve serum $\mathrm{D}$ vitamini $\left(25(\mathrm{OH}) \mathrm{D}_{3}\right)$ düzeyi arasındaki ilişkinin incelendiği başka bir çalışmada, $\mathrm{D}$ vitamini düzeyi ile depresyon arasında önemli bir ilişki bulunmamış ve serum D vitamini düzeyinin genç kadınlarda depresyon biyobelirteci olarak kullanılmasının gerekli olmadığı sonucuna varılmıştır (Kwasky ve Groh, 2012).

Yaşlı bireyler, D vitamininin böbreklerde aktif forma dönüşmesinde ve barsak emiliminde azalma olmasından dolayı D vitamini yetersizliği riski taşımaktadır. Eve bağımlı olan yaşlılarda ise güneşlenme süresinin de sınırlı olması bu riski daha da artırmaktadır (Penckofer, Kouba ve Byrn, 2010). Çalışmalarda, yaşıı bireylerde serum D vitamininin düşük olması depresyon görülme sıklığı ile ilişkilendirilmiştir (Hoogendijk ve diğerleri, 2008; Stewart ve Hirani, 2010). NHANES III verilerinin değerlendirildiği bir çalışmada, 65 yaş üstü bireylerde serum D vitamini düzeylerinin genç yetişkinlere oranla daha düşük olduğu saptanmıştır (Zadshir, Tareen, Pan, Norris ve Martins, 2005). Yaşlılar (60 yaş ve üstü) üzerinde yapılan başka bir çalışmada, yüksek düzeyde D vitamini yetersizliği $(<10 \mathrm{ng} / \mathrm{mL})$ saptanmış ve yaşın artması ve sağlık durumlarının kötüleşmesine bağlı olarak depresyon görülme sıklığının da arttığı belirtilmiştir. Ayrıca çalışmada şiddetli D vitamini eksikliği olan bireylerde depresyon gelişme riski, iki kat daha fazla bulunmuştur (Lapid, Cha ve Takahashi, 2013).

Çalışmalarda gösterilen plazma D vitamini düzeyi ve obezite arasındaki negatif ilişkinin nedeni tam olarak açıklanamasa da, $25(\mathrm{OH}) \mathrm{D}_{3}$ 'ün enerji harcamasını düzenlediği düşünülmektedir (Marcotorchino ve diğerleri, 2014). Vücut algısından kaynaklanan kaygının da obez bireylerin güneşlenmelerini engellediği ve buna bağlı olarak plazma D vitamini düzeylerinde düşüş olduğu bilinmektedir (Penckofer, Kouba ve Byrn, 2010). Kuzey Norveç'te obez bireyler üzerinde yapılan plesabo kontrollü bir çalışmada, serum $25(\mathrm{OH}) \mathrm{D}_{3}$ düzeyleri 40 nmol/L'den düşük olan fazla kilolu ve obez kişilerde depresyon belirtileri oldukça yüksek çıkmış, bir yıl boyunca yüksek doz D vitamini (20.000 ve $40.000 \mathrm{IU} / \mathrm{hafta})$ suplemanı verilen grupta plasebo grubuna göre depresyon skorlarında önemli iyileşmeler gözlenmiş ve 
yetersizliğin mevsimsel veya klinik yetersizlik sonucu mu olduğunun belirlenmesi önerilmiştir (Jorde, Sneve, Figenschau, Svartberg ve Waterloo, 2008).

\section{Vitamini Eksikliği Depresyonda Önemli Rol Oynayabilir Mi?}

\section{Depresyonun patofizyolojisi}

Depresyonun patofizyolojisi üzerine; genetik ve epigenetik faktörlerin yanı sıra, temel olarak farklı iki hipotez ileri sürülmektedir. Birincisi, depresyonun beyindeki monoamintransmitterlerin kullanılabilirliği ve işlevi ile bağlantılı olduğu "monoamin eksikliği hipotezi"dir. Monoaminlerin depresyonla ilişkisinde ki en önemli kanıt, antidepresan ilaç etkinliğinin gözlemlenmesiyle elde edilmiştir. Antidepresanlar çeşitli mekanizmalar yoluyla sinapslardaki seratonin ve norepinefrin düzeylerini ve postsinaptik nöron ateşlenmesini artırmaktadır. Bir diğer hipotez ise, psikolojik işleyişte stresin etkileridir. Stres cevabında hipotalamus, kortikotropin salgılatıcı hormon (CRH) salgılamakta ve bu hormon hipofiz bezini kortikotropin salgılaması için uyarmaktadır. Kortikotropin ise adrenallerden kortizol salgılatmaktadır. Hipotalamus-hipofiz-adrenal eksenin işleyişindeki bozukluk, depresyonun yanı sıra anksiyete ile ilişkili olabilmektedir. D vitamininin rolü de dahil olmak üzere depresyonun çok sayıda nedeni ve birçok alt tipi bulunmakta ve karmaşık bir hastalık olduğunun da vurgulanması gerekmektedir (Bertone-Johnson, 2009).

\section{D vitamini, beyin işlevleri ve depresyon mekanizması}

Serum/plazma 25(OH)D düzeyinin düşük olması ile depresif semptomlar arasında ilişki olduğuna dair bulgular gün geçtikçe artmaktadır. Kesitsel çalışmalar ve prospektif veriler de, düşük $\mathrm{D}$ vitamini düzeyinin artmış depresyon riskiyle ilişkili olduğunu desteklemektedir (Lansdowne ve Provost, 1998; Sanders ve diğerleri, 2011). D vitamininin aktif ve aktif olmayan her iki formu da kan beyin bariyerini geçebilmekte (Shipowick, Moore, Corbett ve Bindler, 2009) ve bir nörosteroid olduğu düşünülmektedir (Bertone-Johnson, 2009). Yapılan çalışmalarda, merkezi sinir sistemindeki glial hücreler ve nöronlar da dahil olmak üzere hemen hemen tüm dokularda ve beynin birçok alanında D vitamini reseptörleri saptanmış ve depresyonun patofizyolojisinde D vitamininin etkisi olabileceği ileri sürülmüştür. $\mathrm{Bu}$ bölgelerin çoğunda 25(OH)D'yi 1,25(OH)D'ye metabolize eden 1- $\alpha$ hidroksilaz enzimi önemli immünoreaktivite gösterdiği saptanmıştır (Eyles, Smith, Kinobe, Hewison ve McGrath, 2005; Prüfer, Veenstra, Jirikowski ve Kumar, 1999; Drevets, Price ve Furey, 2008; Berk ve diğerleri, 2013). 
D vitamininin; nöronal farklılaşma, akson bağlantısı, dopaminontogenezi, beyin yapısı ve işlevi ile ilişkisini gösteren klinik veriler mevcuttur. Fetal yaşam ve çocukluk dönemindeki D vitamini eksikliği ile erken yaşamda gözlenen otistik spektrum bozukluğu ve şizofreni gibi gelişimsel esaslı bozukluklar, bu ilişkinin varlığını güçlendirilmektedir (Eyles, Burne ve McGrath, 2013). Ancak mekanizmalar ve geçerliliklerini netleştirebilmek için kapsamlı çalışmalara gerek duyulmaktadır (Humble, 2010).

Son yıllarda yapılan epidemiyolojik çalışmalarda ise düşük D vitamini düzeyinin depresyon, Alzheimer hastalığı gibi beyin gelişimindeki anomalilerle ilişkili olmayan psikiyatrik hastalıklarla da ilişkili olduğu gösterilmiştir (Peeyush ve diğerleri, 2010; Kumar ve diğerleri, 2011). D vitamininin merkezi sinir sistemi (MSS) üzerine olası 4 mekanizma ile etkili olabileceği düşünülmektedir (Humble, 2010):

- D vitamininin aktif formu olan 1,25(OH)2D3, MSS'deki birçok mekanizmada nörosteroid gibi rol almaktadır. Özetle, kalsitrol bazı nörotransmitterlerin sentez ve degredasyonunda etkili olarak birçok nörotropik faktörün düzenlenmesinde rol almakta ve beyin oksidatif koruma sistemini desteklemektedir.

- Kalsitrol nörotransmitterler ile ilgili olarak, tirozin hidroksilazın gen ekspresyonunu aktive etmekte, dopamin, nöradrenalin ve adrenalinin kullanılabilirliklerini artırmaktadır. Aynı zamanda kolin asetiltransferazın aktivitesini artırırken, asetilkolinesterazın aktivitesini azaltmaktadır. Dopamin, noradrenalin ve asetilkolin mood bozuklukları, dikkat eksikliği/hiperaktivite ve Alzheimer hastalığı ile ilişkilidir.

- Kalsitrol, NGF (nerve growth factor), GDNF (glial derived neurotrophic factor) ve NT-3 (neurotrophin 3)'ün artışına, NT-4 (neurotrophin 4)'ün azalmasına neden olmaktadır. NGF, GDNF, NT-3 ve NT-4'ün Alzheimer, depresyon, şizofreni ve parkinson hastalıklarında etkili olduğu bilinmektedir.

- D vitamini, $\gamma$-glutamil transpeptidazın gen ekspresyonunu artırarak, beyin glutatyon seviyesini artırmakta ve beyni oksidatif dejenerasyonuna karşı korumaktadır.

\section{Depresyon tedavisinde beslenmenin yeri}

Depresyonun en yaygın tedavileri; antidepresan tedavisi ve psikoterapidir. Dünya sağlık örgütü verilerine göre (WHO, 2008) depresyon tedavisinde başarı oranı \%60-80'dir, ancak depresyonu olan kişilerin \%25'ten daha azı tedavi görmektedir. Hastalar; ekonomik durum, bağımlılık korkusu, ilaç kullanma gerekliliğinin ortadan kalktığının düşüncesi veya ilaçların istenmeyen yan etkileri nedeniyle kullandıkları ilaçları bırakmaktadır. İlaç tedavisini 
bırakanlarda, depresyonun tekrarlama oranı daha yüksektir. Beslenme tedavisinde özellikle beslenme desteklerinin kullanımı, incelenmesi gereken önemli konulardan biridir (Penckofer, Kouba ve Byrn, 2010). Depresyon ve diğer mental bozukluklarda D vitamini yetersizliğinin saptanması ve tedavi edilmesi, kolay, ucuz ve etkili bir tedavi yaklaşımı olmasının yanı sıra yaşam kalitesini de artırmaktadır (Humble, 2010).

Depresyon ve diğer mental bozuklukların tedavisinde kanıta dayalı beslenme önerileri belirlenmemiştir. Örneğin; folik asit, $B_{12}$ vitamini, selenyum, demir, çinko gibi mineraller ve bazı yă̆ asitleri alımının depresyon tedavisi üzerine etkili olabileceğine dair bilgiler mevcuttur, ancak ne kadar alınması gerektiği bilinmemektedir. Majör depresyon, bipolar bozukluk, şizofreni ve obsesif kompulsif bozukluklar gibi mental hastalıklarda beslenme yetersizlikleri ve tedavi yaklaşımları Tablo 1'de özetlenmiştir (Penckofer, Kouba ve Byrn, 2010). 
Tablo 1. Bazı mental bozuklukların beslenmeye bağlı nedenleri ve alternatif tedavi önerileri

\begin{tabular}{|c|c|c|}
\hline Mental bozukluklar & Nedeni & Alternatif tedavi \\
\hline \multirow[t]{7}{*}{ Majör depresyon } & Serotonin eksikliği & Triptofan \\
\hline & Dopamin/noradrenalin eksikliği & Tirozin \\
\hline & GABA* eksikliği & GABA \\
\hline & Omega-3 eksikliği & Omega-3 \\
\hline & Folat/vitamin B eksikliği & Folat/vitamin B \\
\hline & Magnezyum eksikliği & Magnezyum \\
\hline & $\mathrm{SAM}^{* *}$ eksikliği & SAM \\
\hline \multirow[t]{6}{*}{ Bipolar bozukluk } & Asetilkolin reseptörlerinin fazlalı̆̆ 1 & Lityum oratat, taurin \\
\hline & Vanadyum fazlalığı & Vitamin C \\
\hline & Vitamin B/folat eksikliği & Vitamin B/folat \\
\hline & L- triptofan eksikliği & L-triptofan \\
\hline & Kolin eksikliği & Lesitin \\
\hline & Omega-3 eksikliği & Omega-3 \\
\hline \multirow[t]{3}{*}{ Şizofreni } & Serotonin sentezinde bozulma & Triptofan \\
\hline & Glisin eksikliği & Glisin \\
\hline & Omega-3 eksikliği & Omega-3 \\
\hline
\end{tabular}

\section{D vitamininin güvenli kullanımı ve toksisitesi}

Günümüzde dünyada bir milyarı aşkın insanda D vitamini eksikliği ve yetersizliği olduğu tahmin edilmektedir. D vitamini eksikliğinin saptanmasının en iyi yolu serum $25(\mathrm{OH}) \mathrm{D}_{3}$ düzeyine bakmaktır. D vitamini eksikliği $20 \mathrm{ng} / \mathrm{mL}$ 'den az, D vitamini yetersizliği ise $30 \mathrm{ng} / \mathrm{mL}$ 'den az olarak tanımlanmaktadır (Penckofer, Kouba ve Byrn, 2010).

D vitamini ile yapılan tüm güvenlik ve toksisite çalışmaları, $<4000 \mathrm{IU} /$ gün tüketimin güvenilir olduğunu göstermektedir (Howland, 2011; IOM, 2010). D vitamini toksisitesinin potansiyel sonuçları; hiperkalsemi, böbrek taşları, yumuşak ve vasküler doku kalsifikasyonudur. Hiperkalseminin klinik belirtileri; bulantı, kusma, artmış susuzluk hissi ve depresyondur (Howland, 2011). 
Yüksek doz D vitamini suplemantasyonunun hafif depresif semptomları iyileştirebildiği gösterilmiş olsa da, orta ve ağır depresyonlu bireylerin ruh halini iyileştirip iyileştirebileceği ve serum D vitamini düzeyi yeterliliğinin depresyonun tekrarlamasında koruyucu olup olmadığının belirlenmesi önemlidir (Bertone-Johnson, 2009).

D vitamini eksikliği ve duygu durum bozukluklarının yaşlılar arasında çok yaygın olduğunu gösteren bir çalışmada düşük D vitamini (<400 IU/gün) alan yaşlı kadın bireylerde yaşam kaliteleri, daha yüksek D vitamini alanlara göre daha düşük bulunmuştur. Yaşlılarda yaşam kalitesini iyileştirmek için günlük olarak önerilen miktarda ( $\geq 400 \mathrm{IU} /$ gün) D vitamini alımının önemli olduğu vurgulanmıştır (Motsingera, Lazovicha, MacLehosea, Torkelsond ve Robiena, 2012).

Norveç'te yapılan bir çalışmada, düşük serum $25(\mathrm{OH}) \mathrm{D}_{3}$ düzeylerinin depresif semptomlar ile ilişkili olduğu, ancak D vitamini suplementasyonunun önemli bir etkisinin olmadı ̆̆ı bulunmuştur (Kjærgaard ve diğerleri, 2012).

Postmenopozal kadın bireylerde (36.282 kişi) D vitamini (400 IU) ve elemental kalsiyum (1000 mg) suplemetasyonunun depresyon üzerine etkisinin incelendiği çift kör bir çalışmanın iki yıllık sonucunda, D vitamini ve kalsiyum suplemantasyonunun etkili olmadığı, depresyonun önlenme ve tedavisinde, yüksek doz D vitaminin etkili olup olmayacağının araştırılması gerektiği sonucuna varılmıştır (Bertone-Johnson ve diğerleri, 2012).

Depresyonun patofizyolojisiyle ilişkilendirilse de henüz depresyonlu hastalara D vitamini suplemantasyonu ile ilgili güçlü kanıtlar bulunmamaktadır. Fakat bu hastaların yaşam şekli ve yaşadığı bölgenin coğrafik özelliklerine de bağlı olarak D vitamini yetersizliği risklerinin olabileceği göz önünde bulundurulmalıdır. Güneş ışığına maruz kalma ve diyetle alınan D vitamini düzeyleri de göz önünde bulundurularak D vitamini suplemantasyonu yapılmalıdır. (Berk ve diğerleri, 2007; Humblea, 2010; Parker ve Brotchie, 2011; Li ve değerleri, 2013).

D vitamini yetersizliği açısından riskli olan bebekler için anne sütü önemlidir, fakat anne sütü D vitamini açısından fakirdir. Bu nedenle; Amerikan Pediatri Akademisi, D vitamini ile güçlendirilmiş formula almaya başlayana kadar bebeklere ilk birkaç gün 400 IU D vitamini suplemantasyonunu önermektedir (Penckofer, Kouba ve Byrn, 2010). Ülkemizde ise T.C. Sağlık Bakanlığı (2013) 2005 yılı Mayıs ayından itibaren ülke genelinde 1 yaş altı çocuklara 400U/gün (3 damla) olacak şekilde ücretsiz olarak D vitamini desteği vermektedir. 
Gür ve arkadaşları (2014) Ankara ilinde yapıkları bir çalışmada, anneler ve yenidoğan bebeklerinde serum D vitamini yetersizliğinin annelerde $\% 62.6$, bebeklerde ise $\% 58.6$ olduğu saptanmıştır. D vitamini yetersizliğinin anne ve bebek sağlığı açısından halen önemli bir halk sağlığı sorunu olduğu belirtilmiştir (Gür ve diğerleri, 2014).

\section{Sonuç ve Öneriler}

D vitaminin kemik sağlığı için önemli olduğu bilinmektedir, ancak diğer fizyolojik fonksiyonları ve depresif bozukluklarla olan ilişkisi halen araştırılmaktadır. Bazı kesitsel, klinik ve epidemiyolojik çalışmalarda, depresif belirtilerin yüksek olduğu gruplar veya depresyon tanısı almış hastalarda D vitamini düzeyinin düşük olduğu gösterilmiştir. Ancak, D vitamini eksikliği ile depresyon gelişme riski arasındaki ilişkiyi değerlendiren ve D vitamini suplemantasyonunun tedavide etkili olduğu gösteren yeterli çalışma bulunmamaktadır.

Yetişkin, genç, obez, yaşlı ve kronik hastalığı olan bireylerin D vitamini eksikliği ve depresyon riski altında olabileceği göz önünde bulundurulmalıdır. Gelecekte yapılacak araştırmalarda, D vitamini suplementasyonu ve depresyon arasındaki ilişkiyi belirleyen çalışmalar yapılmalıdır.

Depresyon ve diğer mental hastalıklardan korunmada açık havada egzersiz yapmak, gün içerisinde güneşli bir saatte 15 dakika yürüyüşe çıkmak, D vitamininden zengin ve/veya zenginleştirilmiş yiyecek ve içecekler tüketmek, besin destekleri ile D vitamini düzeyini iyileştirmek, mental sağlığı iyileştirmenin basit ve en ucuz çözümüdür. Güneş 1şığı, normal serum D vitamini düzeyini korumak için en etkili araçtır. Haftada 2-3 kez, kol ve bacaklar açık olacak şekilde 5-10 dakika güneşlenmek, D vitamini yetersizliği ve/veya eksikliğinden korunmak için yararlıdır. Güneşlenme süresi; günün saati, mevsim, enlem gibi farklılıklardan etkilendiği için evrensel öneriler yapmak zordur.

Depresyon ve D vitamini eksikliği ve/veya yetersizliği arasındaki olası ilişki nedeniyle bu bireylerde serum/plazma D vitamini düzeylerinin belirlenmesi önerilebilir.

\section{Çıkar Çatışması}

Yazarlar ya da yazı ile ilgili bildirilen herhangi bir çıkar çatışması yoktur. 


\section{Kaynakça}

Anglin, R.E., Samaan, Z., Walter, S.D., \& McDonald, S.D. (2013) Vitamin D deficiency and depression in adults: systematic review and meta analysis. The British Journal of Psychiatry, 202:100-107.

Baysal, A. (2012) Beslenme. (13. Baskı). Ankara: Hatipoğlu yayınevi.

Berk, M., Sanders, K.M., Pasco, J.A., Jacka, F.N., Williams, L.J., Hayles, A.L., ve diğerleri. (2007) Vitamin D deficiency may play a role in depression. Medical Hypotheses, 69:1316-1319.

Berk, M., Williams, L.J., Jacka, F.N., O'Neil, A., Pasco, J.A., \& Moylan, S. (2013) So depression is an inflammatory disease, but where does the inflammation come from? BMC Medicine, 11:200216.

Bertone-Johnson, E.R. (2009) Vitamin D and the occurence of depression: casual association or circumstantial evidence. Nutrition Reviews, 67(8): 481-492.

Bertone-Johnson, E.R., Powers, S.I., Spangler, L., Larson, J., Michael, Y.L., Millen, A.E., ve diğerleri. (2012) Vitamin D supplementation and depression in the women's health initiative calcium and vitamin D trial. American Journal of Epidemiology, 176(1):1-13.

Black, L.J., Jacoby, P., Allen, K.L., Trapp, G.S., Hart, P.H., Byrne, S.M., ve diğerleri. (2014) Low vitamin D levels are associated with symptoms of depression in young adult males. Australian \& New Zealand Journal of Psychiatry, 48(5):464-471.

CADTH Rapid Response Reports (2015) Vitamin D Testing in the General Population: A Review of the Clinical and Cost-Effectiveness and Guidelines [Internet]. Source Ottawa (ON): Canadian Agency for Drugs and Technologies in Health.

Drevets, W.C., Price, J.L., \& Furey, M.L. (2008) Brain structural and functional abnormalities in mood disorders: implications for neurocircuitry models of depression. Brain Structure and Function, 213(1-2):93-118.

Dünya Sağlık Örgütü Depression. http://www.who.int/mentalhealth/management/depression/definition/en/print.htm adresinden elde edildi.

Eyles, D.W., Smith, S., Kinobe, R., Hewison, M,. \& McGrath, J.J. (2005) Distribution of the vitamin D receptor and 1 alpha-hydroxylase in human brain. Journal of Chemical Neuroanatomy 29(1):21-30.

Eyles, D.W., Burne, T.H.J., \& McGrath, J.J. (2013) Vitamin D, effects on brain development, adult brain function and the links between low levels of vitamin D and neuropsychiatric disease. Front Neuroendocrinol, 234:47-64.

Gür, G., Abaci, A., Köksoy, A.Y., Anik, A., Catli, G., Kişlal, F.M., ve diğerleri. (2014) Incidence of maternal vitamin D deficiency in a region of Ankara, Turkey: a preliminary study. Turkish Journal of Medical Sciences, 44(4):616-23.

Hoogendijk, W.J., Lips, P., Dik, M.G., Deeg, D.J., Beekman, A.T., \& Penninx, B.W. (2008) Depression is associated with decreased 25-hydroxyvitamin $D$ and increased parathyroidhormone levels in older adults. Archives of general psychiatry, 65(5): 508-512.

Howland, R.H. Vitamin D and depression. (2011) Journal of Psychosocial Nursing and Mental Health Services, 49(2):15-17. 
Humble, M.B. (2010) Vitamin D, light and mental health. Journal of Photochemistry and Photobiology B: Biology, 101:142-149.

Humble, M.B., \& Gustafssonb Bejerota, S. (2010) Low serum levels of 25-hydroxyvitamin D (25OHD) among psychiatric out-patients in Sweden: Relations with season, age, ethnic origin and psychiatric diagnosis. The Journal of Steroid Biochemistry and Molecular Biology, 121:467470.

Intitute of medicine (2010). DRIs for Calcium and Vitamin D. http://www.iom.edu/ /media/Files/Report\%20Files/2010/Dietary-Reference-Intakes-forCalcium-and-Vitamin-D/calciumvitd_lg.jpg adresinden elde edildi.

Jorde, R., Sneve, M., Figenschau, Y., Svartberg, J., \& Waterloo, K. (2008) Effects of vitamin $\mathrm{D}$ supplementation on symptoms of depression in overweight and obese subjects: randomized double blind trial. Journal of Internal Medicine, 264:599-609.

Kjærgaard, M., Waterloo, K., Wang, C.E., Almås, B., Figenschau, Y., Hutchinson, M.S., ve diğerleri. (2012) Effect of vitamin D supplement on depression scores in people with low levels of serum 25-hydroxyvitamin D:nested case control study and randomised clinical trial. British Journal of Psychiatry, 201:360-368.

Kwasky, A.N., \& Groh, C.J. (2012) Vitamin D and depression: Is there a relationship in young women? Journal of the American Psychiatric Nurses Association, 18: 236-243.

Kumar, P.T., Antony, S., Nandhu, M.S., Sadanandan, J., Naijil, G., \& Paulose, C.S. (2011) Vitamin D3 restore saltered cholinergic and insülin receptor expression in the cerebral cortex and muscarinic M3 receptor expression in pancreatic islets of streptozotocin induced diabetic rats. The Journal of Nutritional Biochemistry, 22(5)418-425.

Lansdowne, A.T., \& Provost, S.C. (1998) Vitamin D3 enhances mood in healthy subjects during winter. Psychopharmacology (Berl), 135:319-323.

Lapid, M.I., Cha, S.S., \& Takahashi, P.Y. (2013) Vitamin D and depression in geriatric primarycare patients. Journal of Clinical Interventions in Aging, 8: 509-514.

Li, G., Mbuagbaw, L., Samaan, Z., Zhang, S., Adachi, J.D., Papaioannou, A., ve diğerleri. (2013) Efficacy of vitamin D supplementation in depression in adults: a systematic review protocol. Systematic Reviews, 2:64-71.

Marcotorchino, J., Tourniaire, F., Astier, J., Karkeni, E., Canault, M., Amiot, M.J. ve diğerleri. (2014). Vitamin D protects against diet-induced obesity by enhancing fatty acid oxidation. The Journal of Nutritional Biochemistry, 25(10):1077-83.

McGreevy, C., Barry, M., Davenport, C., Byrne, B., Donaghy, C., Collier, G., ve diğerleri. (2015) The effect of vitamin D supplementation on arterial stiffness in an elderly community-based population. Journal of the American Society of Hypertension, 9(3):176-83.

Motsingera, S., Lazovicha, D., MacLehose, R.F., Torkelson, C.J., \& Robien, K. (2012) Vitamin D intake and mental health-related quality of life in older women: The Iowa Women's Health Study. Maturitas,71:267-273.

Parker, G., \& Brotchie, H. (2011) 'D' for depression: any role for vitamin D? 'Food for Thought' II. Acta Psychiatrica Scandinavica, 124: 243-249.

Peeyush, K.T., Savitha, B., Sherin, A., Anju, T.R., Jes, P., \& Paulose, C.S. (2010) Cholinergic, dopaminergic and insülin receptors gene expression in the cerebellum of streptozotocininduced diabetic rats: functional regulation with Vitamin D3 supplementation. Pharmacology Biochemistry and Behavior, 95(2):216-222. 
Penckofer, S., Kouba, J., \& Byrn, M. (2010) Vitamin D and depression: where is all the sunshine? Issues in Mental Health Nursing,31:385-393.

Prüfer, K., Veenstra, T.D., Jirikowski, G.F., \& Kumar, R. (1999) Distribution of 1,25dihydroxyvitamin D3 receptor immuno reactivity in the rat brain and spinal cord. Journal of Chemical Neuroanatomy, 16(2):135-45.

Sağlık bakanlığı (2013) Bebeklerde D Vitamini Yetersizliğinin Önlenmesi ve Kemik Sağlı̆̆ının Geliştirilmesi Programı. http://cocukergen.thsk.saglik.gov.tr/daire-faaliyetleri/beslenme/752bebeklerde D vitamini yetersizlinin önlenmesi ve kemik sağllğının geliştirilmesi programı.html adresinden elde edildi.

Sanders, K.M., Stuart, A.L., Williamson, E.J., Jacka, F.N., Dodd, S., Nicholson, G., ve diğerleri. (2011) Annual high-dose vitamin D3 and mental well-being: randomised controlled trial. British Journal of Psychiatry, 198:357-364.

Shipowick, C.D., Moore, C.B., Corbett, C., \& Bindler, R. (2009) Vitamin D and depressive symptoms in women during the winter: A pilot study. Applied Nursing Research, 22:221-225.

Stewart, R., \& Hirani, V. (2010) Relationship between vitamin D levels and depressive symptoms in older residents from a national survey population. Psychosomatic Medicine, 72(7):608-612.

Williams, R., Novick, M., \& Lehman, E. (2014) Prevalence of hypovitaminosis D and its association with comorbidities of childhood obesity. The Permanente Journal, 18(4):32-9.

Wong, M. (2015) What has happened in the last 50 years in immunology. Journal of Paediatrics and Child Health, 51(2):135-9.

Zadshir, A., Tareen, N., Pan, D., Norris, K., \& Martins, D. (2005) The prevelence of hypovitaminosis D among US adults: data from the NHANES III. Ethnicity \& Disease, 15(4):97-101. 